\title{
Conversion of the planted forest with pinus to grain production in Tibagi, Paraná: a study showing the economic perspectives
}

\author{
Randy Speltz ${ }^{1}$ Risely Ferraz-Almeida ${ }^{1 *}$
}

${ }^{1}$ MBA in agribusiness, University of São Paulo, Luiz de Queiroz College of Agriculture. Av. Padua Dias, 11, 13418-900, Piracicaba, São Paulo, Brazil.

\section{Original Article \\ *Corresponding author: rizely@gmail.com}

Keywords:

Corn

Soybean

Conversion

Pinus sp.

Palavras-chave:

Milho

Soja

Conversão

Pinus sp.

Received in

2020/09/11

Accepted on

2021/06/28

Published in 2021/09/31

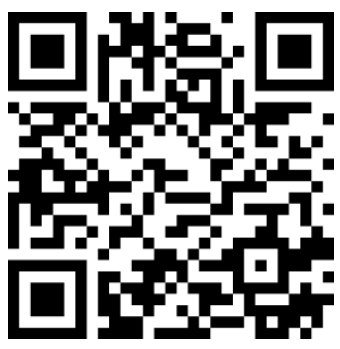

DOI: http://dx.doi.org/ 10.34062/afs.v8i2.11112

\section{(cc) BY}

ABSTRACT: The adequate management of forests is the key for sustainable development with a direct influence on climate change mitigation. In the world, the planted forest lands increased $40 \%$ (from 167.5 to 277.9 million hectares) between 1990 and 2015. However, recently, there is a growing inverse flux from planted forest to grain production areas due to the expansion of grain production in Brazil. The study monitored two economic scenarios (A, continuous planting of pinus; B, conversion of pinus to corn/soybean production) in Tibagi, Paraná, Brazil. Results showed that both the productions of pinus and the soybean/corn are viable economic alternatives. The conversion of pinus to corn/soybean increased net present value, annual net present value, and internal rate of return, respectively from $9.8 \%$; $\$$ 1,519.48; and $\mathrm{R} \$ 160.57$ (planted forest), to $13.7 \%$; $\mathrm{R} \$ 3,389.50 ; \mathrm{R} \$ 304.93$ (soybean/corn). In the conversion, the soybean/corn presented a positive economic flux after the $4^{\text {th }}$ crop year due to the high initial cost of stump removal. While, the pinus showed a positive economic flux after the $7^{\text {th }}$ crop-year with the thinning/harvest in the $7^{\text {th }}, 10^{\text {th }}, 14^{\text {th }}, 16^{\text {th }}$, and $20^{\text {th }}$ years.

\section{Conversão de floresta plantada com pinus para produção de grãos em Tibagi, Paraná: um estudo mostrando as perspectivas econômicas}

RESUMO: O manejo adequado das florestas é fundamental para o desenvolvimento sustentável com uma influência direta na mitigação das mudanças climáticas. No mundo, as áreas de florestas plantadas aumentaram em $40 \%$ (de 167,5 para 277,9 milhões de hectares) entre 1990 e 2015. Porém, recentemente, existe um fluxo inverso crescente de áreas de floresta plantada para áreas de produção de grãos devido à expansão da produção de grãos no Brasil. O estudo monitorou dois cenários econômicos (A, plantio continuo de pinus; e B, conversão de pinus para produção de milho/soja) em Tibagi, Paraná, Brasil. Os resultados mostraram que tanto a produção de pinus quanto a soja/milho são alternativas economicamente viáveis. A conversão de pinus para produção de milho/soja aumentou o valor presente líquido, o valor presente líquido anual e a taxa interna de retorno, respectivamente, de $9,8 \%$; R $\$ 1.519,48$; e R $\$ 160,57$ (floresta plantada), para $13,7 \% ; \mathrm{R} \$ 3.389,50 ; \mathrm{R} \$ 304,93$ (soja/milho). A soja/milho apresentou um fluxo econômico positivo a partir da $4^{\mathrm{a}}$ safra devido ao alto custo inicial da remoção dos tocos. Enquanto, o pinus apresentou fluxo econômico positivo após o $7^{\circ}$ ano-safra com o desbaste/colheita nos $7^{\circ}, 10^{\circ}, 14^{\circ}$, $16^{\circ}$ e $20^{\circ}$ anos. 


\section{Introduction}

The adequate management of forests is a key for sustainable development with a direct influence on climate change mitigation, introducing a bioeconomy and adequate balance of social, economic, and environmental. In the world, the planted forest lands increased $40 \%$ (from 167.5 to 277.9 million hectares) between 1990 and 2015, with a higher increment in the temperate zone $>$ boreal $>$ tropical $>$ subtropical (Payn et al. 2015).

The Brazilian roundwood production of the planted forest is large (145 million cubic meters) (FAO 2017), and turns Brazil into a prominent player on a global scale with an area of 7.8 million hectares (IBA, 2019). Part of this success is explained by the productivity increment from 13 to $40 \mathrm{~m}^{3}$ ha $^{1}$ year ${ }^{-1}$ of roundwood in the last 50 years (Gonçalves et al. 2013). The area with the planted forest is represented mainly by the planting of eucalyptus (Eucalyptus sp.) and pine (Pinus sp.) with a total of $72 \%$ and $20 \%$ (92\% of Brazilian production), respectively. In this sense, eucalyptus occupies 5.7 million hectares of planted forest, located mainly in Minas Gerais (24\%), São Paulo (17\%), and Mato Grosso do Sul (15\%). While, pinus occupies 1.6 million hectares of planted forest, located mainly in Paraná (42\%) and Santa Catarina (34\%). Both pinus and eucalyptus play as important sources of wood, contributing to suppress the illegal exploitation of native wood.

There is a diversity in the conversion fluxes between planted forest and agriculture lands, i.e. (i) conversion from agricultural lands to areas with planted forest; (ii) conversion from degraded pastures to the planted forest; (iii) and conversion of multiuse agriculture lands to systems of agroforest (MCTI, 2015). Recently, there is a growing inverse flux from planted forest to grain production areas due to the expansion of grain production in Brazil. The global consumption of agricultural products (i.e., grains) is projected to grow by $15 \%$ over the coming decade (2019-2028), mainly in regions with high population growth, i.e., SubSaharan Africa, India, the Middle East, and North Africa (OECD-FAO 2019). In 2019/2020, Brazil produced 250,9 million tons of grains with a production of $2.8 ; 10.8 ; 3.0$; 102.3; 120.3 million tons of cotton (Gossypium hirsutum), rice (Oryza sativa), bean (Phaseolus vulgaris; all harvests), corn (Zea mays; all harvests), and soybean (Glycine max), respectively (CONAB 2020). Probably, this positive scenario is increasing the conversion from planted forest to grain production areas. Byerlee et al. (2014) showed that market-driven intensification causes land expansion and deforestation, especially when commodities present high prices.

The hypothesis raised is that the positive scenario of grain production is responsible for increasing the flux of conversion from the planted forest to grain production areas. This study aimed to evaluate the economic viability of conversion from planted forests to the production of grains, taking into account the conversion costs (clearing, cleaning, and soil management).

\section{Material and Methods \\ Area characterization}

The study was established in a familiar farm located in Tibagi, Paraná, Brazil $\left(24^{\circ}\right.$ $30^{\prime} \mathrm{S}$; $50^{\circ} 24^{\prime} \mathrm{W} ; 748 \mathrm{~m}$ ), in 2019 . The area presents a climate classified as $\mathrm{Cfb}$ (Temperate oceanic climate; Köppen classification) with a temperature ranging from 12 to $28{ }^{\circ} \mathrm{C}$, and an annual total rainfall of $1335 \mathrm{~mm}$ welldistributed (Alvares et al., 2013).

The farm has experience with pinus planting since 1972, with an initial area of 308,9 hectares. Recently, the farm is diversified with planted forests of pinus (Pinus taeda) and eucalyptus (Eucalyptus grandis, eucalyptus urograndis, and Eucalyptus saligna), and a total area of 1.400 hectares (70\% Pinus and 30\% eucalyptus). Agriculture lands are managed with the planting of soybean, corn, and wheat totaling an area of 700 hectares. All managements of grains and planted forests are performed according to Casão Junior et al. (2012). Soil is classified as an Oxisol (Soil taxonomy, 2014), corresponding to a Latossolo in the Brazilian Classification System (EMBRAPA, 2018) with a clay texture and content of 568; 136; and $295 \mathrm{~g} \mathrm{~kg}-1$ of clay, silt, and sand, respectively (0.0-0.4 m soil depth).

\section{Scenarios and costs}

We simulated two scenarios: scenario A (continuous planting of the planted forest with pinus, managed for 20-years) and scenario B (conversion of the planted forest with pinus to the planting of corn and soybean). The cost data were monitored during 2011 and 2018. In both 
scenarios, initially, the soil was prepared using a conventional system (plowing, disking, harrowing, and furrowing) with the incorporation of dolomitic lime and gypsum before planting, aiming to achieve $70 \%$ of base saturation. The application of lime, gypsum, and fertilization was performed on pinus and soybean according to their need.

In scenario $\mathrm{A}$, the calculus of cost considered soil management, seedlings, planting, silvicultural treatments, and pruning. The pinus was planted in a spacing of planting $2.5 \times 2.5 \mathrm{~m}$, with a total of 1600 trees per hectare. The pruning was carried out in the $3^{\text {rd }}$, $5^{\text {th }}$, and $7^{\text {th }}$ years after the planting with a height of 2.5; 4.5; and $7.0 \mathrm{~m}$, respectively. The last pruning occurred in the remaining trees, approximately 800 trees per hectare. In the first year, there was ant control with the application of insecticide to avoid the leaf-cutting ant attack. The planting and re-planting (5 to $10 \%$ of seedlings) were performed with seedlings obtained locally. In the six initial years, there were chemical controls of weeds with applications of herbicide (glyphosate; $2.5 \mathrm{~L} \mathrm{ha}^{-}$ ${ }^{1}$ ), and an additional cost of manual weed control in initial development. The pruning was performed mechanically in the $3^{\text {rd. }} ; 5^{\text {th}}$; and $7^{\text {th }}$ years. The costs of thinning and harvest were (i) the mechanical operation, (ii) maintenance, (iii) fuel, (iv) and depreciation of equipment. After the harvest, the production of roundwood was monitored in the $7^{\text {th }}, 10^{\text {th }}, 14^{\text {th }}, 16^{\text {th }}$, and $20^{\text {th }}$ years. The economic inputs were calculated according to (i) production (volume and ton), (ii) the diameter of roundwood, (iii) and the price paid. Where, the diameters of 8-17; 18-24; 25-35; and $>35 \mathrm{~cm}$, corresponded to prices paid of R\$ 93,66; 145,00; 195,00; and R \$ 280,00 ha1 , respectively. The cost and prices were demonstrated in $\mathrm{R} \$$ to demonstrate the Brazilian reality.

In scenario $\mathrm{B}$, we considered the initial conversion from the planted forest with pinus (after harvest) to a succession of soybean (inseason) and corn (off-season). Initially, there was stump removal using a hydraulic drill coupled to a backhoe. The use of a hydraulic drill is an alternative to remove roots and stump with low cost and impact and incorporation of roots in soil (Gatto et al. 2003). To soybean planting, weeds were controlled with the application of herbicide (glyphosate; $2.5 \mathrm{~L} \mathrm{ha}^{-}$ $\left.{ }^{1}\right)$. The soil was prepared with the application of lime (2-4 Mg ha ${ }^{-1}$ ) and fertilizers (phosphorus and potassium; rate of $350 \mathrm{~kg} \mathrm{ha}^{-1}, 00-20-20+$ Boron, $\left.1 \mathrm{~kg} \mathrm{ha}^{-1}\right)$. Treated seeds were planted (Variety, BRS 232), and the incidence of diseases and pests were monitored and controlled when requested. Harvest was performed using a mechanical harvester with a productivity average ranging from 3,000 and $3,500 \mathrm{~kg} \mathrm{ha}^{-1}$ of soybean. To corn planting, the soil was prepared with the application of fertilizers in planting (nitrogen, phosphorus, and potassium; $400 \mathrm{~kg} \mathrm{ha}^{-1}$ of 12-32-00 + Zinc, $3 \mathrm{~kg} \mathrm{ha}{ }^{-1}$ ) and covering (nitrogen and potassium; $350 \mathrm{~kg} \mathrm{ha}^{-1}$, formulation: 20-00-20). Treated seeds were planted (Variety, Dow 2B688 HX), and diseases and pests were monitored and controlled when requested. Harvest was performed using a mechanical harvester (Caterpillar $320 \mathrm{CL}$, model $3066 \mathrm{~T}$ ). Wither crop was stabilized with the planting of black oat (Avena strigosa Schreb.) using a planting density of $5.43 \mathrm{~kg} \mathrm{ha}^{-1}$.

In all scenarios, the cost of the mechanical application included taxes, depreciation, and labor. The cost with fertilizers, lime, and pesticides (insecticides, fungicides, herbicides) refers to price averages in the region of study. The costs with impost (8,68 \% of gross income), administrative services (10\% of gross income), and land (R\$

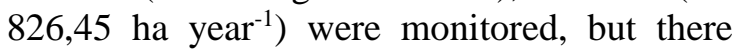
were not used in comparison due to the similar costs in both areas with pinus and grains.

Economic indicator measurements and Statistic analysis

The net present value (NPV) was calculated according to the present monetary value of the cash flows (including investment and salvage value) discounted at the appropriate discount rate (Vieira Sobrinho 2000). The NPV was calculated using Eq. 1, where, FC: is the values of cash flows; $t$ : is the time; FC0: is the initial cash flow; and $\mathrm{i}$ : is the rate of financial transaction considering a rate of $8.5 \%$ (Selic rate for the last two years: 2017, 10\%; and 2018, $6 \%$ ), (ADVFN 2020).

$$
\mathrm{NPV}=\sum_{t=1}^{n} \frac{F C_{t}}{(1+i)^{t}}-F C_{0}
$$

The annual net present value (ANPV) was calculated basing on the NPV (Vieira Sobrinho 2000), using Eq. 2. The ANPV is recommended to compared projects with 
different duration (Gitman 1997). Where, NPV: is the net present value; $t$ : is the time (1 year); FC0: is the initial cash flow; and i: is the rate of financial transaction considering a rate of $8.5 \%$ (Selic rate for the last two years: 2017, 10\%; and 2018, 6\%), (ADVFN 2020).

$$
\mathrm{ANPV}=\frac{N P V_{t}}{\sum_{t=1}^{n} \frac{1}{(1+i)^{t}}}
$$

The Internal Rate of Return (IRR) was the metric used in capital budgeting to estimate the profitability of potential investments. The calculus was performed according to Vieira Sobrinho (2000), using Eq. 3. Where, FC0: is the initial cash flow; FC: is the values of cash flows; $t$ : is the time; and $i$ : is the rate of financial transaction considering a rate of $8.5 \%$ (Selic rate for the last two years: 2017, 10\%; and 2018, $6 \%$ ), (ADVFN 2020).

$$
\mathrm{FC}_{0}=\sum_{J=1}^{n} \frac{F C_{t}}{(1+i)^{t}}
$$

\section{Results}

Cost of pinus production

The cost of planting stabilization in the first seven years was separated into soil management and planting, weed and ant controls, and pruning with an impact on 39; 34; and $27 \%$ in total cost, respectively (Table 1 ). There were eight operations to control ants and weed in the first two years, representing a total of $\mathrm{R} \$ 1,326.06 \mathrm{ha}^{-1}$. The cost of all soil management and planting was the highest with $\mathrm{R} \$ 1,504.65 \mathrm{ha}^{-1}$.

\begin{tabular}{|c|c|c|c|c|c|}
\hline \multicolumn{4}{|c|}{ Pinus production } & \multicolumn{2}{|c|}{$\begin{array}{l}\text { Soybean productions } \\
\end{array}$} \\
\hline Year & Management & $\operatorname{Cost}\left(\mathbf{R} \$ h^{-1}\right)$ & Year & Management & Cost $\left(\mathbf{R} \$\right.$ ha $\left.^{-1}\right)$ \\
\hline 0 & Forest project & $92.30(2 \%)$ & 0 & Soil correction & - \\
\hline 0 & Planting location & $210.87(5 \%)$ & 0 & Winter crop & $523.78(14 \%)$ \\
\hline 0 & Ant control & $60.00(2 \%)$ & 0 & Soil preparation & $106.72(3 \%)$ \\
\hline 0 & Opening of plantingpoints & $351.90(9 \%)$ & 0 & Planting & $865.26(24 \%)$ \\
\hline 0 & Weed control ${ }^{1}$ & $180.00(5 \%)$ & 1 & Crop management & $1,050.32(29 \%)$ \\
\hline 0 & Planting & $351.00(9 \%)$ & 1 & Harvest & $481.35(13 \%)$ \\
\hline 0 & Re-planting & $58.58(2 \%)$ & 1 & Transport of grains & $78.03(2 \%)$ \\
\hline 0 & Weed control ${ }^{1}$ & $268.38(7 \%)$ & $0-1$ & Others cost & $565,24(15 \%)$ \\
\hline 0 & Ant control & $35.00(1 \%)$ & & Total & $3,670.70$ \\
\hline 0 & Weed control $^{2}$ & $220.00(6 \%)$ & & & \\
\hline 0 & Weed control ${ }^{1}$ & $60.00(2 \%)$ & & \multicolumn{2}{|c|}{ Corn productions } \\
\hline 0 & Seedling & $440.00(11 \%)$ & Year & Management & $\operatorname{Cost}\left(\mathbf{R} \$\right.$ ha $\left.^{-1}\right)$ \\
\hline 1 & Weed control ${ }^{2}$ & $268.38(7 \%)$ & 0 & Soil correction & $173.10(5 \%)$ \\
\hline 2 & Weed control ${ }^{1}$ & $234.30(6 \%)$ & 0 & Winter crop & $402.59(10 \%)$ \\
\hline 3 & 1 Pruning & $330.15(9 \%)$ & 0 & Soil preparation & $63.73(2 \%)$ \\
\hline 5 & 2 Pruning & $350.15(9 \%)$ & 0 & Planting & $1,226.07(32 \%)$ \\
\hline 7 & 3 Pruning & $351.50(9 \%)$ & 1 & Crop management & $886.34(23 \%)$ \\
\hline \multicolumn{2}{|c|}{ Soil management and planting } & $1504.65(39 \%)$ & 1 & Harvest & $478.10(12 \%)$ \\
\hline \multicolumn{2}{|c|}{ Weed and ant controls } & $1,326.06(34 \%)$ & 1 & Transport of grains & $311.86(8 \%)$ \\
\hline \multicolumn{2}{|c|}{ Pruning } & $1031.80(27 \%)$ & $0-1$ & Others cost & $311,86(12 \%)$ \\
\hline \multicolumn{2}{|c|}{ Total } & $3,862.51$ & & Total & $3,842.13$ \\
\hline
\end{tabular}

Table1. Cost of pinus and corn/soybean production $\left(\mathrm{R} \$ \mathrm{ha}^{-1}\right)$ in Paraná, Brazil.

-1 and 2 represent mechanical/chemical and manual controls of weeds. The cost of agriculture materials is included in the application. The values in the bracket represent the percentage of the total cost.

The highest volume of roundwood was harvested in the $20^{\text {th }}$ year, with a total of 337.7 $\mathrm{Mg} \mathrm{ha}^{-1}$, representing $60 \%$ of total production (Figure 2). The diameter of roundwood was classified from 8 to $35 \mathrm{~cm}$ with a total production concentrated in $25-35 \mathrm{~cm}(208.5 \mathrm{Mg}$ $\mathrm{ha}^{-1}$ ), following by $18-24$ (203.5 $\left.\mathrm{Mg} \mathrm{ha}^{-1}\right), 8-17$ $\mathrm{cm}\left(154.8 \mathrm{Mg} \mathrm{ha}^{-1}\right)$, and $35 \mathrm{~cm}\left(6.8 \mathrm{Mg} \mathrm{ha}^{-1}\right)$. In the first 14-years, the diameter of roundwood was concentrated in $8-17 \mathrm{~cm}$ and $18-24 \mathrm{~cm}$, with a total production of 97.6 and $57.1 \mathrm{Mg} \mathrm{ha}^{-}$ ${ }^{1}$, respectively. On the other hand, in the last harvest, the diameter of roundwood was concentrated in 25-35 cm (199.9 Mg ha $\left.{ }^{-1}\right)$, following by $18-24\left(88.3 \mathrm{Mg} \mathrm{ha}^{-1}\right), 8-17 \mathrm{~cm}$ (38.7 $\left.\mathrm{Mg} \mathrm{ha}^{-1}\right)$, and $>35 \mathrm{~cm}\left(6.8 \mathrm{Mg} \mathrm{ha}^{-1}\right)$ (Figure 1).

The total cost of pinus management was $\mathrm{R} \$ 52,449.63 \mathrm{ha}^{-1}$ in 20-years, with an annual cost of R $\$ 2,622.48 \mathrm{ha}^{-1}$ year $^{-1}$. In the cash flow, 
the thinning and harvest in the $7^{\text {th }}, 10^{\text {th }}, 14^{\text {th }}$, $16^{\text {th }}$, and $20^{\text {th }}$ year promoted inputs of $\mathrm{R} \$$ $2,202.04 ; 9,088.80 ; 10,185.50 ; 10,911.14$, and $52,842.25$ ha $^{-1}$ with woods sale, respectively. These inputs were associated with outputs of $2,899.19 ;-3,369.02 ;-6,167.11 ;-5,221.06$; and $18,521.22 \mathrm{ha}^{-1}$, referring to the cost of harvest, respectively in the $7^{\text {th }}, 10^{\text {th }}, 14^{\text {th }}, 16^{\text {th }}$, and $20^{\text {th }}$ years. The last harvest presented the highest economic input and was $95 \%$ higher than the first harvest in the 7th year (Figure 2).

. The total outputs and inputs were $\mathrm{R} \$$ 52.499,36 and $\mathrm{R} \$ 85,229.74 \mathrm{ha}^{-1}$, respectively, which generated a positive balance of $R \$$ $32,730.11 \mathrm{ha}^{-1}$ in 20 years (Figure 2).

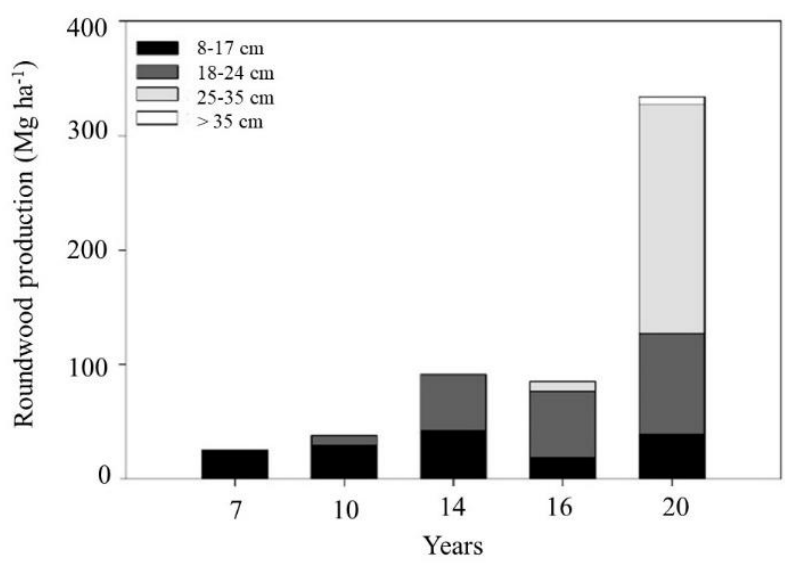

Figure 1. Production of roundwood $\left(\mathrm{Mg} \mathrm{ha}^{-1}\right)$ in an area with Pinus for 20 years $(7,10,14,16$, and 20 years), Paraná, Brazil.
Outputs

Pinus production

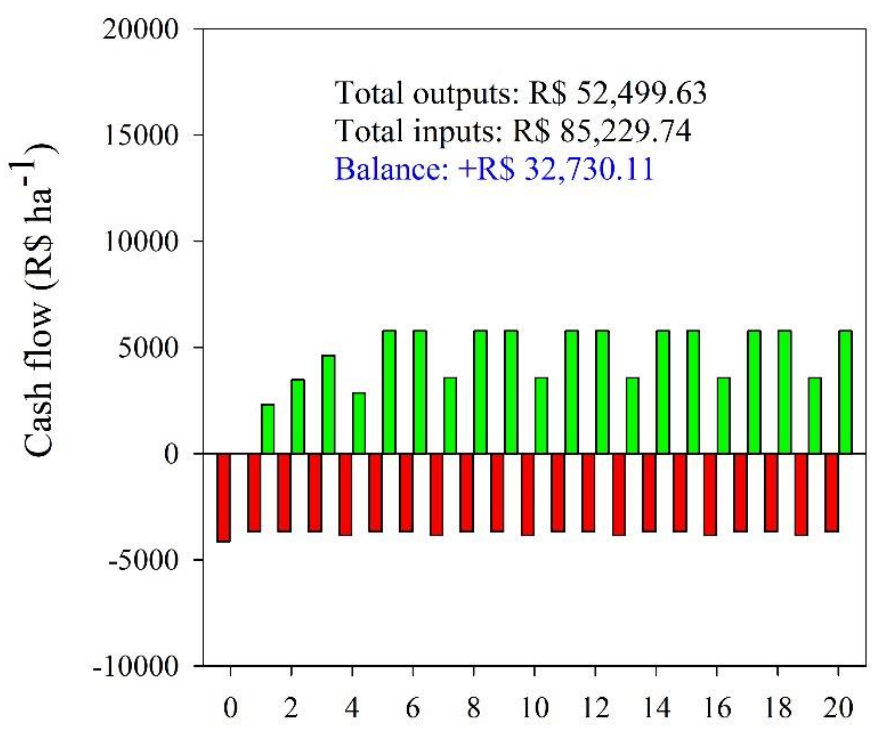

Soybean/corn production

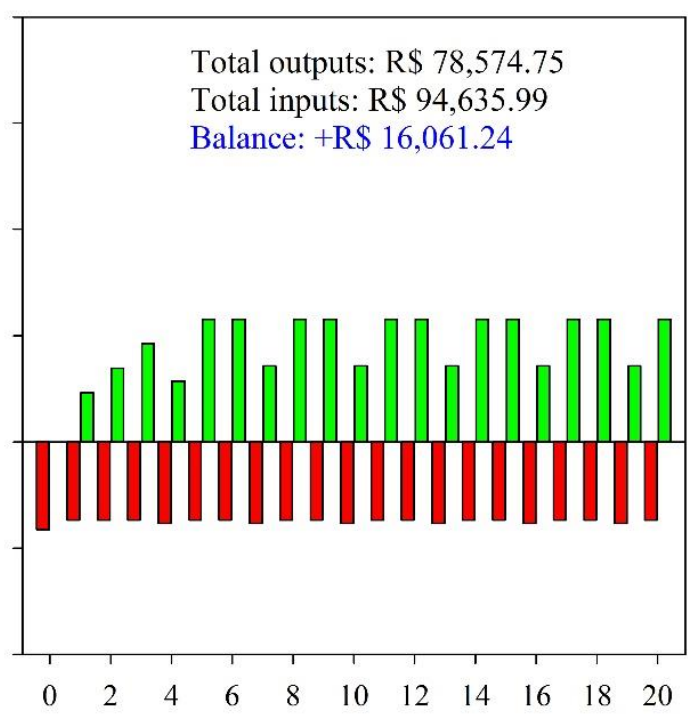

Years

Figure 2. Cash flow $\left(\mathrm{R} \$ \mathrm{ha}^{-1}\right)$ to the production of pinus and soybean/corn (grain) during 20 years, Paraná, Brazil. Thinning and harvest were performed in the $7^{\text {th }}, 10^{\text {th }}, 14^{\text {th }}, 16^{\text {th }}$, and $20^{\text {th }}$ years.

\section{Cost of corn/soybean production}

The total cost of corn production was R\$ 3,842.13 ha $^{-1}$ year $^{-1}$, considered 5\% higher than soybean production ( $\mathrm{R} \$ 3,670.70 \mathrm{ha}^{-1}$ year $^{-1}$ ). This difference was caused by additional costs in soil correction and higher costs in planting and transport of grains (up to $50 \%$ ), Table 1 . Focusing on soybean production, crop management presented a higher concentration in the total cost (29\%), followed by the cost of planting, soil correction, and harvest. Soil correction was not performed in soybean due to the winter crop. The higher costs in planting and crop management also were found in corn production (Table 1).

The cash flux to corn and soybean production in conversion from an area with the planted forest of pinus was negative in the first year $\left(\mathrm{R} \$-4.132,23 \mathrm{ha}^{-1}\right)$ due to the use of stump removal. Annually, the production of corn/soybean generated an average output and inputs of $\mathrm{R} \$-3,722.13 \mathrm{ha}^{-1}$ and $\mathrm{R} \$+4,731.80$ 
ha $^{-1}$, respectively (Figure 2). In 20-years, the total outputs and inputs were $\mathrm{R} \$-78,574.75$ and $\mathrm{R} \$+94,635.99 \mathrm{ha}^{-1}$, which generated a positive balance of R $\$ 16,061.24$ ha $^{-1}$ (Figure 2).

\section{Economic indicators}

The corn/soybean production presented an IRR, NPV, and ANPV of $13.7 \%, \mathrm{R} \$$ 3,389.50 ha ${ }^{-1}$, and $\mathrm{R} \$ 304.93 \mathrm{ha}^{-1}$, respectively. These values were considered higher than values of pinus production with an IRR; NPV, and ANPV of $9.8 \% ; \mathrm{R} \$ 1,784.78 \mathrm{ha}^{-1}$; and $\mathrm{R} \$$ $160.57 \mathrm{ha}^{-1}$, respectively (Table 2 ).

\section{Discussion}

The high cost of pinus production was associated with the thinning and harvest, which also was found by Coelho and Coelho (2012), Lopes et al. (2007), and Drinko et al. (2015). This high cost of harvest due to the high technology of mechanical harvesters with cutting and extracting of trees. A harvester is a machine that works on cutting, debarking, delimbing, and cutting on logs of predetermined length, leaving the logs grouped and removing from the forest (da Silva et al. 2010; Drinko et al. 2015). Lopes et al. (2007) showed that the average operational cost of the harvester is US\$ 115,72 per hour of work, with a production cost of US $\$ 3,56 \mathrm{~m}^{3}$. The cost of harvest can achieve approximately $50 \%$ of the total cost (Moreira 1992). The diameter of roundwood increased from 10 to 20 years with the highest volume of roundwood in the 20-year, representing a total of $337.7 \mathrm{Mg} \mathrm{ha}^{-1}$ and $60 \%$ of total production with the diameter concentrated in $25-35 \mathrm{~cm}$ $(199.9 \mathrm{Mg})$. Dossa et al. (2002) showed that after 20 years, the pinus production could achieve a mean of $450 \mathrm{~m}^{3}$ of roundwood, and there is an increase of production from the first to the last harvest. Silva et al. (2010) and Lopes et al. (2007) demonstrated that harvesting efficiency is increased with a greater diameter of roundwood. Focusing on the cost of planting stabilization, there were low costs of ants and weed controls, but with a high number of operations, which impacted significantly in total cost. The controls of weed and ants are requested in the first years to avoid the loss of production. There is a natural attack of leafcutting (Acromyrmex crassispinus) after planting with a higher intensity in the first 30 days (Link et al. 2000). Generally, recommend the re-planting of 5 to $10 \%$ of seedling to substitute the plant attacked by ants or plants with low development (Dossa et al. 2002). The attack of leaf-cutting can cause losses in diameter and height of plants with defoliation of pinus (Nickele et al. 2012).

Table 2. Net present value (NPV), annual net present value (ANPV), and internal rate of return (IRR) to the production of pinus, and corn and soybean after the conversion from the planted forest with Pinus.

\begin{tabular}{lcc}
\hline Economic indicators & Pinus & Corn/Soybean \\
\hline IRR $(\%)$ & 9.8 & 13.7 \\
NPV $\left(\mathrm{R} \$ \mathrm{ha}^{-1}\right)$ & $1,784.78$ & $3,389.50$ \\
ANPV $\left(\mathrm{R} \$ \mathrm{ha}^{-1}\right)$ & 160.57 & 304.93 \\
\hline
\end{tabular}

In the cash flow, the thinning and harvest in the $7^{\text {th }}, 10^{\text {th }}, 14^{\text {th }}, 16^{\text {th }}$, and $20^{\text {th }}$ years promoted inputs with woods sale. The last harvest presented the highest input and was 95 $\%$ higher than the first harvest in the $7^{\text {th }}$ year. The highest economic inputs in the last years also were found by Dossa et al. (2002), who showed an input of $\mathrm{R} \$ 12,451.23 \mathrm{ha}^{-1}$ to a production of $480 \mathrm{~m}^{3}$ of roundwood. Studies of Coelho and Coelho (2012) showed that the first inputs happened in the $7^{\text {th }}$ year with thinning of $50-60 \%$ of plants. Specifically, Coelho and Coelho (2012) showed the production of 50 and $70 \mathrm{~m}^{3}$ of roundwood, which promoted an input between $\mathrm{R} \$ 750,00$ and $1.050,00 \mathrm{ha}^{-1}$ in the $7^{\text {th }}$ year with thinning. With economic indicators, the pinus presented positive IRR, NPV, and
ANPV with values of $9.8 \%, \mathrm{R} \$ 1,784.78 \mathrm{ha}^{-1}$, and $\mathrm{R} \$ 160.57 \mathrm{ha}^{-1}$, respectively. These results indicated that the cultivation of pinus is a viable alternative to the Tibagi region, Paraná. Positive economic indicators to pinus production also are presented in the literature (Coelho and Coelho 2012; Rodigheri 2002; Álvaro et al. 200). Dossa et al. (2002) showed values of IRR, NPV, and ANPV similar to our study, with respective values of $11 \%, \mathrm{R} \$ 1,942.04 \mathrm{ha}^{-1}$, and R\$ $165.08 \mathrm{ha}^{-1}$. Vitale and Miranda (2010) also found a higher IRR (27\%) in the South-center region of Parana. Rodigheri (2002) showed that in the systems of agroforests (pinus with corn and bean), there was a change of IRR from 17.09 to $16.64 \%$ (first year), and from 17.09 to $20.02 \%$ (second year), comparing pinus alone. 
The conversion of pinus planted forest to corn/soybean promoted an increase of net present value, annual net present value, and internal rate of return with values of $13.7 \%$; $\$$ 3,389.50; R\$304.93, respectively. Alves et al. (2008), comparing the economic viability of soybean, cotton, and sugarcane, noticed that soybean was most attractive with a high return of investment, followed by cotton and sugarcane in the region of Goiás, Brazil. Richetti et al. (2018) showed that the total cost of soybeans was 2 and 5\% lower than corn production in season and off-season, respectively. In our study, both productions of soybean and corn are economically viable, as demonstrated in the literature (Oliveira et al. 2016; Richetti et al. 2018). Crop management and planting presented a higher concentration of total cost and are accorded to Alves et al. (2008). The cost of agriculture products (i.e., fertilizers, lime, seeds, insecticides, fungicides, and herbicides) is commonly higher and impact negatively on the cost of soybean and corn production. In 2011, Hirakuri (2011) showed that the cost with agricultural products was between $\mathrm{R} \$ 561.73$ and $\mathrm{R} \$ 758.74 \mathrm{ha}^{-1}(40-50$ $\%$ of total cost) in soybean production in Paraná. Oliveira et al. (2016) showed that there is a variation from 26 to $50 \%$ of the soybean profitability rate, according to market-driven. There are positive perspectives of economic gains in soybean production in the next years (OECD-FAO 2019), explaining the increase of soybean areas. Byerlee et al. (2014) showed that market-driven intensification causes land expansion and deforestation, especially when commodities present high prices. Gazzoni et al. (2019) described that there is an increase of soybean area in Brazil associated with better use of lands, and recovering and occupying pasture areas, degraded or not.

\section{Conclusion}

Pinus planted forest and soybean/corn are viable economic alternatives in Tibagi, Paraná. The conversion of pinus planted forest to corn/soybean promoted an increase of net present value, annual net present value, and internal rate of return, respectively from $9.8 \%$; $\mathrm{R} \$ 1,519.48$; and $\mathrm{R} \$ 160.57$ (planted forest) to $13.7 \% ; \quad \mathrm{R} \$ 3,389.50 ; \quad \mathrm{R} \$ 304.93$ (soybean/corn). With the soybean/corn after conversion of pinus planted forest, there was a high initial cost of stump-removal. While, the pinus planted forest showed a positive economic flux after the $7^{\text {th }}$ crop-year with thinning/harvest in the $7^{\text {th }}, 10^{\text {th }}, 14^{\text {th }}, 16^{\text {th }}$, and $20^{\text {th }}$ years.

\section{References}

ADVFN (2020) Taxa SELIC: Valor Anual $e$ Mensal. https://br.advfn.com/indicadores/taxaselic. Accessed 24 Jun 2020

Álvaro N, Oliveira D, Scolforo A, et al (2007) Viabilidade econômica de um sistema agroflorestal economical feasibility of an agroforestry system. Cerne, 13(1):96-106

Alvares CA, Stape JL, Sentelhas PC, Gonçalves JLM, Sparovek G (2013) Köppen's climate classification map for Brazil. Meteorol, 22: 711728.

Alves LRA, Ballaminut CEC, Osaki M, et al (2008) Viabilidade econômica da produção de algodão, soja e cana-deaçúcar no estado de Goiás. In: Sociedade Brasileira de Economia, Administração e Sociologia Rural. Rio Branco, pp $1-23$

Byerlee D, Stevenson J, Villoria N (2014) Does intensification slow crop land expansion or encourage deforestation? Glob. Food Sec, 3(1):92-98

Casão Junior R, Araújo A, Llanillo R (2012) Plantio direto no Sul do Brasil: Fatores que facilitaram a evolução do sistema $e \quad o$ desenvolvimento $d a \quad$ mecanização conservacionista. Resultados da pesquisa Resultado da Web com links de sites Instituto Agronômico do Paraná - IAPAR, Londrina Coelho M, Coelho M (2012) Potencialidades Econômicas de Florestas Plantadas de Pinus. Revista Paranaense de Desenvolvimento, 123(1):257-278

Elliottii em Pequenas Propriedades Rurais. Rev Parana Desenvolvimento, ISSN-e 2236-5567, No 123, 2012, págs 257-278 257-278

CONAB (2020) Conab - Boletim da Safra de Grãos, 80 Levantamento - Safra 2019/20. https://www.conab.gov.br/info-

agro/safras/graos/boletim-da-safra-de-graos.

Accessed 24 Jun 2020

da Silva EN, Machado CC, Minette LJ, et al (2010) Avaliação técnica e econômica do corte mecanizado de Pinus sp. com harvester. Rev Arvore, 34(4):745-753. https://doi.org/10.1590/s010067622010000400019

Dossa D, Damin da Silva H, Francisco Jurado Bellote A, Roque Rodigheri H (2002) Produção e Rentabilidade de Pínus em Empresas Florestais. Colombo 
Drinko C, Lopes E, Oliveira F (2015) Produtividade e custos do corte de pinus com harvester de pneus e esteiras productivity and cost of pine cut with harvesters of tires and track wheel. Enciclopédia Biosf, 11(22):3664-3677. https://doi.org/10.18677/Enciclopedia_Biosfera_ 2015_254

EMBRAPA - Empresa Brasileira de Pesquisa Agropecuária. Sistema Brasileiro de Classificação de Solos (2018). 5th ed. Rio Janeiro: Embrapa.

FAO - Food and Agriculture Organization of the United Nations. Forest products - year book (2019). Rome. http://www.fao.org/3/ca5703m/ca5703m.pdf. Accessed 24 Mar 2021

Gatto A, Barros NF de, Novais RF et al (2003) Efeito do método de preparo do solo, em área de reforma, nas suas características, na composição mineral e na produtividade de plantações de Eucalyptus grandis. Rev Árvore, 25:635-646. https://doi.org/10.1590/s0100-

67622003000500006

Gazzoni D, Cattelan A, Nogueira M (2019) $O$ aumento da produção brasileira de soja representa uma ameaça para a floresta amazônica? EMBRAPA, publicações.

Gitman L (1997) Princípios de administração financeira, 7th edn. Harbra, São Paulo

Gonçalves JL de M, Alvares CA, Higa AR, et al (2013) Integrating genetic and silvicultural strategies to minimize abiotic and biotic constraints in Brazilian eucalypt plantations. For Ecol Manage, 301:6-27. https://doi.org/10.1016/j.foreco.2012.12.030

Hirakuri M (2011) Avaliação do desempenho econômico-financeiro da produção de soja no Estado do Paraná, para a safra 2011/12. Embrapa Soja Circ Técnica 1-18

IBA (2019) Relatório 2019, Report 2019. https://iba.org/ (accessed July 3, 2020).

Link H, Link F, Link D (2000) Controle da formiga-preta-pastadeira, Acromyrmex crassispinus, com formicida em pó. Ciência Floretal, 10(1):45-56

Lopes E, Cruziniani E, Dias A, César Fiedler N (2007) Avaliação técnica e econômica do corte de madeira de pinus com cabeçote harvester em diferentes condições operacionais. Floresta, 37(3):305-313

MCTI - Ministério da Ciência, Tecnologia e Inovação (2015) Setor uso da terra, mudança do uso da terra e florestas, Relatório Referência. Brasília.

http://redd.mma.gov.br/images/FREL/RR_LULU CF_Mudana-de-Uso-e-Floresta.pdf

Moreira M (1992) O desenvolvimento da mecanização na exploração florestal sob ótica dos custos. In: Curso de atualização sobre sistemas de exploração sobre sistemas de exploração e transporte florestal, 7th ed. FUPEF, Curitiba, pp 161-170

Nickele MA, Filho WR, de Oliveira EB, et al (2012) Leaf-cutting ant attack in initial pine plantations and growth of defoliated plants. Pesqui Agropecu Bras, 47(7):892-899. https://doi.org/10.1590/S0100-

204X2012000700003

OECD-FAO (2019). OECD-FAO Agricultural Outlook 2019-2028. Paris

Oliveira P, Cervi R, Rodrigues S, Campos B (2016) Analise dos custos de produção para o cultivo da soja em cenários distintos de produtividade e preço no interior paulista. Rev do Agronegócio, 5(1):58-66

Payn T, Carnus J-M, Freer-Smith P, et al (2015) Changes in planted forests and future global implications. Forest Ecology and Management, 352 (2015) 57-67. https://doi.org/10.1016/j.foreco.2015.06.021

Richetti A, Ferreira L, Staut L (2018) Custos de Produção de Soja e Milho Safrinha em Chapadão do Sul, MS, da Safra 2016/2017. Embrapa, comunicado técnico.

Rodigheri R (2002) Viabilidade econômica de plantios florestrais solteiros $e$ de sistemas agroflorestais. Brasília. Embrapa Florestas, comunicado técnico.

Salton J, Hernani L, Fontes C (1998) Sistema Plantio direto, 5th edn. EMBRAPA, Dourados.

Soil taxonomy. Keys to Soil Taxonomy, NRCS Soils.

(2014).

https://www.nrcs.usda.gov/wps/portal/nrcs/detail /soils/survey/class/taxonomy/?cid=nrcs142p2_05 3580 (accessed July 3, 2020).

Vieira Sobrinho J (2000) Matemática financeira. Editora Atlas, 1st edition. São Paulo

Vitale V, Miranda G de M (2010) Análise comparativa da viabilidade econômica de plantios de pinus taeda e eucalyptus dunnii na região centro-sul do Paraná. Floresta, 40(3): 469-476. doi: 10.5380/rf.v40i3.18908 